\title{
Ethylenediaminetetraacetic Acid (EDTA) as an Auxiliary Tool in the Electrospray Ionization Mass Spectrometry Analysis of Native and Derivatized $\beta$-Cyclodextrins, Maltoses, and Fructans Contaminated with $\mathrm{Ca}$ and/or Mg
}

\author{
Silvana L. Giudicessi, ${ }^{\text {a }}$ M. Kaniz Fatema, ${ }^{\mathrm{b}}$ Hiroshi Nonami, ${ }^{\mathrm{b}}$ and \\ Rosa Erra-Balsells ${ }^{\mathrm{a}}$ \\ a CIHIDECAR-CONICET, Departamento de Química Orgánica, Facultad de Ciencias Exactas y Naturales, \\ Universidad de Buenos Aires, Buenos Aires, Argentina \\ ${ }^{b}$ Plant Biophysics/Biochem. Research Laboratory, Faculty of Agriculture, Ehime University, Matsuyama, \\ Japan
}

The effect of $\mathrm{Ca}^{2+}$ (and $\mathrm{Mg}^{2+}$ ) and the disodium salt of ethylenediaminetetraacetic acid (EDTA), a well known $\mathrm{Ca}^{2+}$ (and $\mathrm{Mg}^{2+}$ ) chelating agent, on the volatilization/ionization of carbohydrates by using electrospray ionization mass spectrometry has been studied. Model compounds such as maltoses (maltose to maltoheptaose), $\beta$-cyclodextrins ( $\beta$-cyclodextrin, methyl- $\beta$-cyclodextrin, heptakis(2,6-di-O-methyl)- $\beta$-cyclodextrin, heptakis(2,3,6-tri-O-methyl)- $\beta$ cyclodextrin, and 2-hydroxypropyl- $\beta$-cyclodextrin) and fructans (sucrose, 1-ketose, nystose, and 1F-fructofuranosylnystose) were used. (J Am Soc Mass Spectrom 2010, 21, 1526-1529) (c) 2010 Published by Elsevier Inc. on behalf of American Society for Mass Spectrometry

I mportant advances in the direct analysis of soluble carbohydrates present in plant cells and tissues, such as probe electrospray (PESI) mass spectrometry (MS) [1], pressure probe and ultraviolet matrix assisted laser desorption/ionization (UV-MALDI) MS [2], and direct UV-MALDI-MS of tissues [3-6], have been recently reported. Studies of carbohydrate MS analysis generally deals with complex mixtures isolated from dry powdered plant tissues [7-10]. Carbohydrates soluble in cell sap are in an aqueous solution containing cations such as $\mathrm{K}^{+}(50-100 \mathrm{mM}), \mathrm{Na}^{+}(5.0-5.5 \mathrm{mM})$, as well as $\mathrm{Mg}^{2+}$ and $\mathrm{Ca}^{2+}(<2.5 \mathrm{mM})$ [11]. Thus, soluble carbohydrates are detected in MS positive ion mode mainly as potassiated species $\left([\mathrm{M}+\mathrm{K}]^{+}\right)[1-9]$ and in negative mode as deprotonated species $\left([\mathrm{M}-\mathrm{H}]^{-}\right)$by using either sucked cell sap [2] or direct cell/tissue MS analysis [1, 3-6].

The situation is quite different for native carbohydrate samples obtained after extraction because cell walls are included in the plant material and its $\mathrm{Ca}^{2+}$ content is high [11]. The average natural content of cations in dried plant material is $\mathrm{K}^{+} 1 \%, \mathrm{Ca}^{2+} 0.5 \%$, and $\mathrm{Mg}^{2+} 0.2 \%$ [11]. Furthermore, the content of $\mathrm{Na}^{+}$and the $\mathrm{Na}^{+} / \mathrm{K}^{+}$ratio can change drastically due to use of different aqueous solutions and chemicals used during

Address reprint requests to Professor R. Erra-Balsells, Departamento de Química Orgánica, FCEN, UBA, Ciudad Universitaria, 1428-Buenos Aires, Argentina. E-mail: erra@qo.fcen.uba.ar isolation, fractioning, and purification of carbohydrates. Thus, in these samples, the content of $\mathrm{Na}^{+}$is higher than $\mathrm{K}^{+}$, which leads to the formation of mainly the sodiated species $[\mathrm{M}+\mathrm{Na}]^{+}$together with variable amounts of the species $[\mathrm{M}+\mathrm{K}]^{+},[\mathrm{M}+\mathrm{Ca}]^{2+}$, and $[\mathrm{M}+$ $\mathrm{Mg}^{2+}[7-10]$.

To improve the MS analysis of native extracted carbohydrates, which might contain a significant amount of $\mathrm{Ca}^{2+}$ (and/or $\mathrm{Mg}^{2+}$ ), we studied the effect of $\mathrm{Ca}^{2+}$ (and $\mathrm{Mg}^{2+}$ ) and the disodium salt of ethylenediaminetetraacetic acid (EDTA), a well known $\mathrm{Ca}^{2+}$ (and $\mathrm{Mg}^{2+}$ ) chelating agent [12], on the volatilization/ionization of carbohydrates using as ionization method electrospray ionization (ESI).

\section{Experimental}

\section{Materials and Methods}

Carbohydrates (Glucose (Glc), maltose $\left(\mathrm{Glc}_{2}\right)$, maltotriose $\left(\mathrm{Glc}_{3}\right)$, maltotetraose $\left(\mathrm{Glc}_{4}\right)$, maltopentaose $\left(\mathrm{Glc}_{5}\right)$, maltohexaose $\left(\mathrm{Gl}_{6}\right)$, maltoheptaose $\left(\mathrm{Glc}_{7}\right), \beta$-cyclodextrin $(\beta-\mathrm{CD})$, methyl- $\beta$-cyclodextrin $(\mathrm{M}-\beta-\mathrm{CD})$, heptakis (2,6-di-O-methyl)- $\beta$-cyclodextrin (DM- $\beta$-CD), heptakis (2,3,6-tri-O-methyl)- $\beta$-cyclodextrin (TM- $\beta$-CD), and 2hydroxypropyl- $\beta$-cyclodextrin (OHPM- $\beta$-CD) and inorganic salts (sodium, potassium, calcium and magnesium chloride) were obtained from Sigma Chemical Co. Ltd., Tokyo, Japan. Fructans [fructose (F), 
sucrose (F $\{2\})$, 1-ketose ( $F\{3\})$, nystose ( $F\{4\})$ and $1 F$-fructofuranosylnystose (F $\{5\})]$ and the disodium salt dihydrate of ethylenediaminetetraacetic acid (EDTA) were obtained from Wako Pure Chemical Industries, Ltd, Japan. Acetonitrile (MeCN) and methanol (MeOH) (Sigma-Aldrich HPLC grade), were used as purchased without further purification. Water of very low conductivity (Milli-Q grade; 56-59 nS/cm with PURIC-S; ORUGANO Co., Ltd., Tokyo, Japan) was used.

\section{ESI-TOF-MS Experiments}

Because clusters such as $\left[\mathrm{M}+(\mathrm{MeCN})_{n}+\mathrm{Ca}\right]^{2+}$ were detected when acetonitrile was used, water-acetonitrile (MeCN) mixtures was not used as solvents [13-15]. The ESI-TOF mass spectra were acquired using a Mariner Applied Biosystems (Foster City, CA, USA) ESI-TOF mass spectrometer, and 9:1 (vol/vol) $\mathrm{MeOH}-\mathrm{H}_{2} \mathrm{O}$ as solvent stream. A Harvard PHD 2000 syringe pump (Holliston, MA, USA) at a flow-rate of $5 \mathrm{~L} \mathrm{~min}^{-1}$ was used to introduce the carbohydrate solution. The spray tip potential was $+3.69 \mathrm{kV}$, the nozzle potential was $+100 \mathrm{~V}$ and the skimmer voltage was $+15 \mathrm{~V}$. The nozzle temperature was $137^{\circ} \mathrm{C}$. The carbohydrates were dissolved in $1 \mathrm{~mL}$ water ( $\mathrm{pH}$ 6.20-6.80). Carbohydrate solution $(100 \mu \mathrm{L})$ was mixed with the proper volume of salt solution to give solutions containing carbohydrate to salt molar ratio from 100:1 to 1:10 with a $0.1 \mu \mathrm{mol} / \mathrm{mL}$ carbohydrate concentration. Each solution and subsequent solutions made by a 1 in 10 dilution, was injected into the mass spectrometer. The ratios of carbohydrate to metal and to EDTA were varied to study the EDTA effect on the ESI were determined by using carbohydrate concentrations of 10 to $100 \mathrm{pmol} / \mu \mathrm{L}$, and carbohydrate to $\mathrm{CaCl}_{2}$ molar ratios $1: 1,1: 5$, and $1: 10$. The solutions compared in these experiments had carbohydrate to EDTA ratios of 100:1, $50: 1,20: 1,10: 1,5: 1,2: 1,1: 1,1: 5$, and 1:10 (mol/mol). Aqueous carbohydrate solutions with molar ratios of carbohydrate- $\mathrm{CaCl}_{2} 1: 1$ (mol/mol) $(\mathrm{pH}$ 6.30-6.50) were used with enough EDTA to insure calcium to EDTA molar ratios 1:1 and 1:10. Experiments with $\mathrm{MgCl}_{2}$ were conducted in a similar way.

\section{Results and Discussion}

\section{Adding EDTA}

Ethylenediaminetetraacetic acid (EDTA), as well as its different sodium salt forms, is a good chelator for $\mathrm{Ca}^{2+}$ and $\mathrm{Mg}^{2+}$ [12]. In connection with the ESI-MS analysis of carbohydrates, EDTA has only been used to show that the exchange reactions between the carrageenan molecules and the surrounding matrix, whereby protons furnished by the acidic matrix (ethylenediaminetetraacetic acid), take place with one or more $\mathrm{Na}^{+}$ ions [16]. To the best of our knowledge, EDTA has never been used to "clean" native carbohydrate sam- ples contaminated with $\mathrm{Ca}^{2+}$ and/or $\mathrm{Mg}^{2+}$ through chelation. Recently, the specific metal interactions $\left(\mathrm{Na}^{+}\right.$, $\mathrm{Mg}^{2+}$ ) in nucleic acids have been studied using chelators in nanoESI-MS [17].

To check the efficiency of EDTA as a selective chelator in ESI-MS several experiments using the linear maltoses, $\beta$-CD and fructans mentioned above as models were conducted. To an aqueous solution containing either a $1: 1$ or $1: 10$ carbohydrate to $\mathrm{CaCl}_{2}$ molar ratio, EDTA was added in 1:1 and $1: 10 \mathrm{CaCl}_{2}$ to EDTA molar ratio. Aqueous solution of the corresponding carbohydrate and EDTA, in 1:1 and 1:10 molar ratio, were used as control solutions. The ESI-MS analysis of the samples was conducted before and after EDTA addition and showed that for linear maltoses $\mathrm{Glc}_{2}$ to $\mathrm{Glc}_{6}$, similar intensity for the $[\mathrm{M}+\mathrm{Na}]^{+}$signals were observed. Similarly, for Glc $_{7}$ and $\beta-\mathrm{CD}$ the intensity for the pair of $[\mathrm{M}+\mathrm{Na}]^{+}$and $[\mathrm{M}+2 \mathrm{Na}]^{2+}$ signals was similar. Maltoses and $\beta-C D$ showed higher affinity for $\mathrm{Ca}^{2+}$ and/or higher stability of the gas species $[\mathrm{M}+\mathrm{Ca}]^{2+}$ than did fructans. This calcium-containing signal was completely eliminated when EDTA was added to the aqueous carbohydrate- $\mathrm{CaCl}_{2}$ solution.

\section{Application to Substituted $\beta-C D$}

For this study, several commercial $\beta$-cyclodextrin derivatives $(\mathrm{M}-\beta-\mathrm{CD}, \mathrm{DM}-\beta-\mathrm{CD}, \mathrm{TM}-\beta-\mathrm{CD}$, and $\mathrm{OHP}-\beta-$ CD) were used. The corresponding ESI mass spectra showed that these derivatives consisted of a mixture of $\beta-C D$ with different degrees of substitution. DM- $\beta-C D$ showed the expected molecular ion $\left[\left(\mathrm{CH}_{3}\right)_{14}-\beta-\mathrm{CD}\right]$ together with the species with more methyl groups than predicted $\left[\left(\mathrm{CH}_{3}\right)_{15}-\beta-\mathrm{CD}\right]$ and $\left[\left(\mathrm{CH}_{3}\right)_{16}-\beta-\mathrm{CD}\right]$ as three monosodiated ions $\left(\left[\left(\mathrm{CH}_{3}\right)_{14}-\beta-\mathrm{CD}+\mathrm{Na}\right]^{+},\left[\left(\mathrm{CH}_{3}\right)_{15}-\beta-\right.\right.$ $\mathrm{CD}+\mathrm{Na}]^{+}$, and $\left.\left[\left(\mathrm{CH}_{3}\right)_{16}-\beta-\mathrm{CD}+\mathrm{Na}\right]^{+}\right)$, and the corresponding disodiated species $\left[\left(\mathrm{CH}_{3}\right)_{14}-\beta-\mathrm{CD}+\right.$ $2 \mathrm{Na}]^{2+},\left[\left(\mathrm{CH}_{3}\right)_{15}-\beta-\mathrm{CD}+2 \mathrm{Na}\right]^{2+}$, and $\left[\left(\mathrm{CH}_{3}\right)_{16}-\beta-\mathrm{CD}+\right.$ $2 \mathrm{Na}]^{2+}$. The $[\mathrm{M}+2 \mathrm{Na}]^{2+}$ signal intensities were similar to the $[\mathrm{M}+\mathrm{Na}]^{+}$signals. DM- $\beta-\mathrm{CD}$ showed not only the signals corresponding to the expected disodiated species but also additional high intensity satellite signals (Figure 1a), which were completely eliminated after adding EDTA to the aqueous DM- $\beta$-CD solution [Figure 1b; DM- $\beta$-CD:EDTA 1:1 (mol/mol)]. To prove that these additional signals were $[\mathrm{M}+\mathrm{Ca}]^{2+}$ and/or $[\mathrm{M}+\mathrm{Mg}]^{2+}$ species, several experiments were conducted. To a DM- $\beta-C D: \mathrm{CaCl}_{2}$ 1:1 (mol/mol) aqueous solution, an increasing amount of EDTA was successively added [Figure $1 \mathrm{c}$ and $\mathrm{d}, \mathrm{CaCl}_{2}$ :EDTA $1: 1$ and $1: 10$ $(\mathrm{mol} / \mathrm{mol})]$. Similar experiments were performed using $\mathrm{MgCl}_{2}$ instead of $\mathrm{CaCl}_{2}$, mixtures of $\mathrm{CaCl}_{2}+\mathrm{MgCl}_{2}$ (1:1) and treatment of the carbohydrate- $\mathrm{MgCl}_{2}$ (or $\left.\mathrm{CaCl}_{2}+\mathrm{MgCl}_{2}\right)$ mixtures with EDTA. The results obtained are interesting because they show that EDTA can be a useful tool in the ESI-MS analysis of carbohydrates naturally contaminated with $\mathrm{Ca}^{2+}$ and/or $\mathrm{Mg}^{2+}$.

It should be noted that signals of the species $[\mathrm{M}-\mathrm{H}+$ $\mathrm{Ca}]^{+}$and $\left[\mathrm{M}-\mathrm{H}+\mathrm{Mg}^{+}\right.$were not detected for linear 

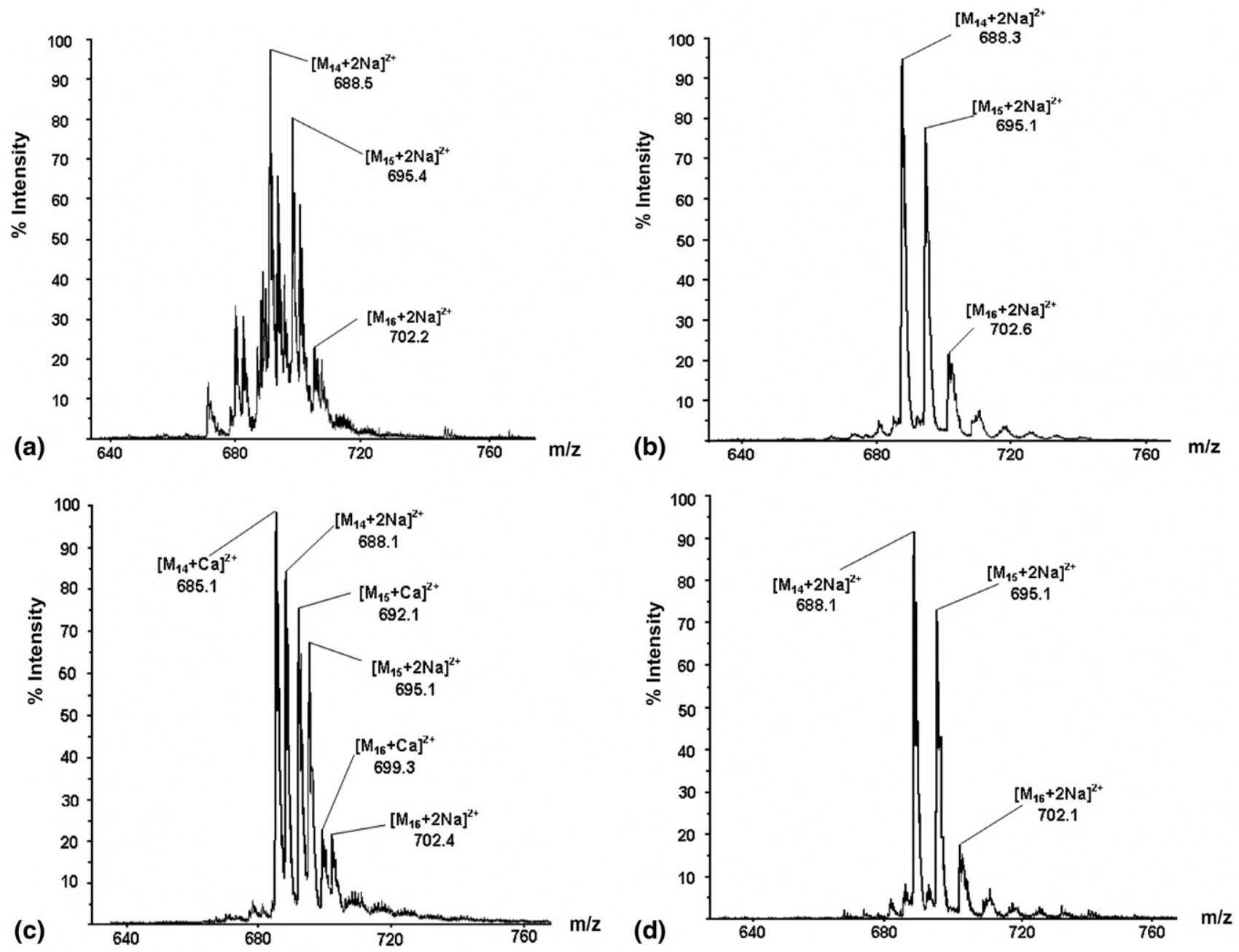

Figure 1. Effect of $\mathrm{CaCl}_{2}$ and EDTA on DM- $\beta$-CD ESI-MS analysis: (a) DM- $\beta$-CD; (b) DM- $\beta$-CD + EDTA 1:1 (mol/mol); (c) DM- $\beta-C D+\mathrm{CaCl}_{2}+$ EDTA 1:1:1 (mol $\left./ \mathrm{mol} / \mathrm{mol}\right) ;(\mathbf{d})$ DM- $\beta-\mathrm{CD}+\mathrm{CaCl}_{2}+$ EDTA 1:1:10 (mol/mol/mol); solvent: water; $m / z$ region: $640-760 \mathrm{Da} ;\left[\mathrm{M}_{n}+2 \mathrm{Na}\right]^{2+}=\left[\left(\mathrm{CH}_{3}\right)_{n}-\beta-\mathrm{CD}\right.$ $+2 \mathrm{Na}]^{2+},\left[\mathrm{M}_{n}+\mathrm{Ca}\right]^{2+}=\left[\left(\mathrm{CH}_{3}\right)_{n}-\beta-\mathrm{CD}+\mathrm{Ca}\right]^{2+}, n=14-16$.

maltoses, fructans or $\beta$-CD. These monocharged satellite signals of the peaks $[\mathrm{M}+\mathrm{Na}]^{+}$and $[\mathrm{M}+\mathrm{K}]^{+}$were observed in the ESI-MS of the $\beta$-CD derivatives studied. As an example, a complex pattern of signals in the $[\mathrm{M}+$ $\mathrm{Na}]^{+}$and $[\mathrm{M}+2 \mathrm{Na}]^{2+}$ regions were observed for $\mathrm{M}-\beta$-CD. The family of eight species from $\left[\left(\mathrm{CH}_{3}\right)_{9}-\beta-\right.$ $\mathrm{CD}$ ] to $\left[\left(\mathrm{CH}_{3}\right)_{16}-\beta-\mathrm{CD}\right]$ was observed in both $\mathrm{m} / \mathrm{z}$ regions. The $\mathrm{m} / \mathrm{z}$ region between 1250 and $1450 \mathrm{Da}$, the $\left[\mathrm{M}+\mathrm{Na}^{+}\right.$region, was also "cleaned" after EDTA addition [Figure 2, M- $\beta$-CD:EDTA 1:1 and 1:10 (mol/ mol)]. Addition of $\mathrm{CaCl}_{2}$ to the $\mathrm{M}-\beta-\mathrm{CD}$ solution clearly increased the intensity of these satellite signals, which were completely eliminated after EDTA addition.

\section{Conclusions}

The $[\mathrm{M}+2 \mathrm{Na}]^{2+}$ species is detected as a peak with a similar or higher intensity than the $[\mathrm{M}+\mathrm{Na}]^{+}$signal in the ESI-MS analysis of $\mathrm{Glc}_{7}, \beta-\mathrm{CD}$, and substituted $\beta$-CD. The $\mathrm{Ca}^{2+}$ and/or $\mathrm{Mg}^{2+}$ adducts formed as de- termined by the observed satellite signals near by the $[\mathrm{M}+2 \mathrm{Na}]^{2+}$ peak. These satellites are detrimental when a mixture of carbohydrates is analyzed, as demonstrated for the $\beta$-CD derivatives (DM- $\beta-C D, M-\beta-C D$, and $\mathrm{OHP}-\beta-\mathrm{CD}$ ). To make the matter worse, these $\beta-\mathrm{CD}$ derivatives also showed satellite signals with the structure $[\mathrm{M}-\mathrm{H}+\mathrm{Ca}]^{+}$and $\left[\mathrm{M}-\mathrm{H}+\mathrm{Mg}^{+}\right.$in the $[\mathrm{M}+$ $\mathrm{Na}]^{+}$and $[\mathrm{M}+\mathrm{K}]^{+} \mathrm{m} / \mathrm{z}$ region (Figure 2 ). In the case of fructans, although the presence of $\mathrm{Ca}^{2+}$ diminishes the intensity of the $[\mathrm{M}+\mathrm{Na}]^{+}$signal, the $[\mathrm{M}+\mathrm{Ca}]^{2+}$ signal is not detected until the fructan: $\mathrm{CaCl}_{2}$ molar ratio was higher than 1:1. This complication can cause serious mistakes in the quantification of fructans.

As a conclusion, the behavior of carbohydrates in the presence of $\mathrm{Ca}^{2+}$ (and $\mathrm{Mg}^{2+}$ ) is not uniform, but rather depends on the carbohydrate structure. The addition of EDTA to a carbohydrate solution quenches the $\mathrm{Ca}^{2+}$ cationizing effect in the ESI spectrum by chelating the divalent cation. Because EDTA does not covalently bind to the carbohydrate, the intensity of the signals 

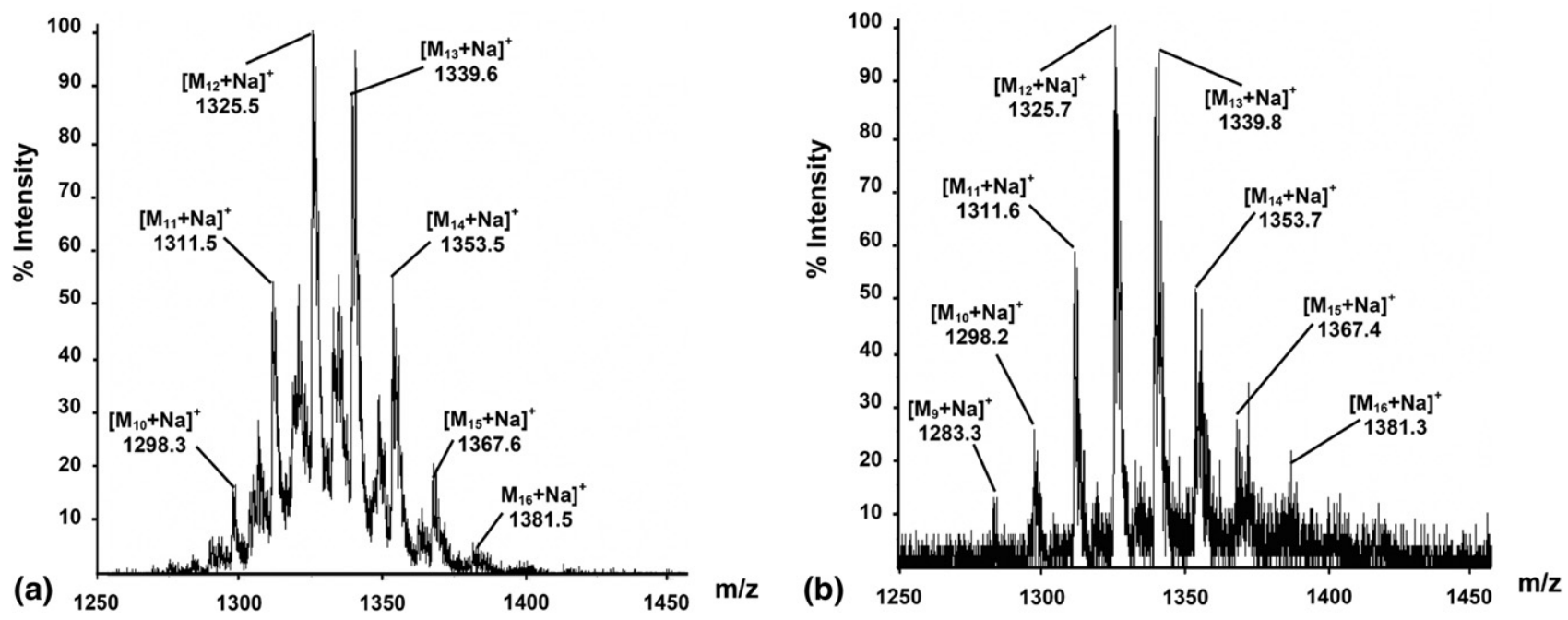

Figure 2. Effect of EDTA on M- $\beta$-CD ESI-MS analysis: (a) M- $\beta$-CD; (b) M- $\beta$-CD + EDTA 1:10 $(\mathrm{mol} / \mathrm{mol})$; solvent: water; $m / z$ region: $1250-1450 \mathrm{Da} ;\left[\mathrm{M}_{n}+\mathrm{Na}\right]^{+}=\left[\left(\mathrm{CH}_{3}\right)_{n}-\beta-\mathrm{CD}+\mathrm{Na}\right]^{+}, n=9-16$.

$[\mathrm{M}+\mathrm{Na}]^{+}$and $[\mathrm{M}+2 \mathrm{Na}]^{2+}$ are restored. The presence of $\mathrm{Ca}^{2+}$ and $\mathrm{Mg}^{2+}$ must be taken into account for qualitative and quantitative ESI-MS analyses of native extracted carbohydrates and carbohydrates in general. In this context, EDTA is a convenient auxiliary reagent that can be used in the ESI- MS analysis of carbohydrates.

\section{Acknowledgments}

The authors acknowledge financial support for this work from the Japan Society for the Promotion of Science (20228004), UBA (X072) and ANPCyT (PICT 06-0615). R.E.-B. is a research member of CONICET.

\section{References}

1. Yu, Z.; Chen, L. C.; Suzuki, H.; Ariyada, O.; Erra-Balsells, R.; Nonami, H.; Hiraoka, K. Direct Analysis of Plant Tissues by Probe Electrospray Ionization Mass Spectrometry. J. Am. Soc. Mass Spectrom. 2009, 20, 2304-2311.

2. Gholipour, Y.; Nonami, Y.; Erra-Balsells, R. Application of Pressure Probe and UV-MALDI TOF MS for Direct Analysis of Plant Underivatized Carbohydrates in Sub-Picoliter Single-Cell Cytoplasm Extract. J. Am. Soc. Mass Spectrom. 2008, 19, 1841-1848.

3. Stahl, B.; Linos, A.; Karas, M.; Hillenkamp, F.; Steup, M. Analysis of Fructans from Higher Plants By Matrix Assisted Laser Desorption/ Ionization Mass Spectrometry. Anal. Biochem. 1997, 246, 195-204.

4. Burrell, M. M.; Earnshaw, C. J.; Clench, M. R. Imaging Matrix Assisted Laser Desorption Ionization Mass Spectrometry: A Technique to Map Plant Metabolites within Tissues at High Spatial Resolution. J. Exp. Bot. 2007, 58, 757-763.

5. Robinson, R.; Warburton, K.; Seymour, M.; Clench, M.; Thomas, J. Localization of Water- Soluble Carbohydrates in Wheat Stems Using
Imaging Matrix-Assisted Laser Desorption Ionization Mass Spectrometry. New Phytol. 2007, 173, 438-444.

6. Gholipour, Y.; Nonami, H.; Erra-Balsells, R. In Situ Analysis of Plant Tissue Underivatized Carbohydrates and On-Probe Enzymatic Degraded Starch by Matrix-Assisted Laser Desorption/Ionization TOF Mass Spectrometry by using Carbon Nantotubes as Matrix. Anal. Biochem 2008, 383, 159-167.

7. Harvey, D. J. Matrix-Assisted Laser Desorption/Ionization Mass Spectrometry of Carbohydrates. Mass Spectrom. Rev. 1999, 18, 349-451.

8. Harvey, D. J. Analysis of Carbohydrates and Glycoconjugates by Matrix-Assisted Laser Desorption/Ionization Mass Spectrometry: An Update Covering the Period 1999-2000. Mass Spectrom. Rev. 2006, 25, 595-662.

9. Harvey, D. J. Analysis of Carbohydrates and Glycoconjugates by Matrix-Assisted Laser Desorption/Ionization Mass Spectrometry: An Update Covering the Period 2001-2002. Mass Spectrom. Rev. 2008, 27, 125-201.

10. Zaia, J. Mass Spectrometry of Oligosaccharides. Mass Spectrom. Rev. 2004, 23, 161-227.

11. Shimizu, S. Plant Physiology, revised ed.; Shokabo Ltd. Co.: Tokyo, Japan, 1993; p. 22.

12. Blaedel, J.; Meloche, V. W. Elementary Quantitative Analysis, Theory, and Practice, 2nd ed.; Harper and Row: NY, 1964; p. 574.

13. Fura, A.; Leary, J. A. Differentiation of $\mathrm{Ca}^{2+}$ - and $\mathrm{Mg}^{2+}$-Coordinated Branched Trisaccharide Isomers: An Electrospray Ionization and Tandem Mass Spectrometry Study. Anal. Chem. 1993, 65, 2805-2811.

14. Sible, E. M.; Brimmer, S. P.; Leary, J. A. Interaction of First Row Transition Metals with $\alpha$ 1-3, $\alpha$ 1-6 Mannotriose and Conserved Trimannosyl Core Oligosaccharides: A Comparative Electrospray Ionization Study of Doubly and Single Charged Complex. J. Am. Soc. Mass Spectrom. 1997, 8, 32-42.

15. Harvey, D. J. Ionization and Collision-Induced Fragmentation of NLinked and Related Carbohydrates Using Divalent Cations. J. Am. Soc. Mass Spectrom. 2001, 12, 926-937.

16. Ackloo, S.; Terlouw, J. K.; Ruttink, P. J. A.; Burgeers, P. C. Analysis of Carrageenans by Matrix Assisted Laser Desorption/Ionization and Electrospray Ionization Mass Spectrometry. I. Kappa Carrageenans. Rapid Commun. Mass Spectrom. 2001, 15, 1152-1159.

17. Turner, K. B.; Monti, S. A.; Fabris, D. Like Polarity Ion/Ion Reactions Enable the Investigation of Specific Metal Interactions in Nucleic Acids and Their Noncovalent Assemblies. J. Am. Chem. Soc. 2008, 130, 13353-13363. 